\title{
Future Child: Pedagogy and the Post-Anthropocene
}

\author{
Alexandra Lakind and Chessa Adsit-Morris
}

\begin{abstract}
Alexandra Lakind is a doctoral candidate at the University of Wisconsin-Madison in Curriculum \& Instruction in the School of Education and Environment \& Resources at the Nelson Institute for Environmental Studies. She is a fellow at the Holtz Center for Science \& Technology Studies, a graduate affiliate of the Center for Culture, History, and Environment, and cofounder of Terra Incognita Art Series. She is currently focusing on human/environmental futures, arts integration, and educational pedagogy. Through implicit and explicit, academic and performative routes, she hopes to foster supportive communities prepared to process unanswerable dilemmas together. Email: llakind@wisc.edu
\end{abstract}

Chessa Adsit-Morris is a curriculum theorist and assistant director of the Center for Creative Ecologies. She is the author of Restorying Environmental Education: Figurations, Fictions, Feral Subjectivities (Palgrave Macmillan, 2017). She is pursuing a PhD in visual studies at the University of California, Santa Cruz. She has worked with universities, NGOs, school boards, and municipal authorities across the world to translate complex scientific research into approachable, teachable theory, creating strategies and resources that help to guide policies and practices toward creating a healthy and more sustainable future.

For many, the Anthropocene foreshadows the apocalypse: a fertile terrain to speculate about the future, which can displace the now. We aim to reconceptualize this era, drawing inspiration from those working to imagine possible eras for the post-Anthropocene-imaginaries that do not deny the material histories and urgencies of the present. In particular, we seek to transform the ways children are figured in this epoch. In this conceptual essay, we (re)consider the Anthropocene, explore how figurations of the child tap into environmental futurism, and call for a pedagogy of the post-Anthropocene which rejects future-orientations that negate children as bearers of their own experience and agents of their own purpose.

Key words: children; pedagogy; futurity; postAnthropocene

into a digital illustration of the earth as a vast, interconnected technological system ${ }^{2}$, and the narrative shifts to one of hope for future generations, concluding with the statement "We have shaped our past, we are shaping our present, we can shape our future" (Gaffney \& Pharand-Deschenes, 2012, n.p.). The globe: a singular shape floating in the dark, vast uncertainty of space, now conceived as a unified network of relations, illustrating a unifying global perspective-we are in this together-one planet, one species, one Anthropocene. This icon, and the accompanying voiceover in the video, uses this "all one" universality to flatten and dissolve difference: It is hard to be all one without being the same.

The Anthropocene, a geological epoch defined by human impact on earth, may be a productive concept; however, 
it may (as we and others argue) function as an all-encompassing ideology-what Jedediah Purdy (2015, para. 12) describes as an "all-purpose projection screen" amplifying preferred (capitalistic and techno-scientific) narratives of human exceptionalism, provoking heroic thinking and high stakes rhetoric "of the human mind pressed up against the wall of apocalypse." The Anthropocene is a universal call to humanity, rather than a focused critique of the vast inequalities regarding who uses resources, who is most at risk, and who is privy to this concept. The Anthropocene comes from the Global North, a geographical designation disproportionately responsible for both the creation and exacerbation of environmental issues and their framing, affecting how we come to know the crisis, imagine it, and respond to it. The Anthropocene, akin to mainstream environmentalism in the United States, invokes visions of universal risk and vulnerability wherein everyone is implicated. Yet everyone is too often depicted as white and middle class, erasing the complex and intertwined histories of colonialism and capitalism that manifest in present-day issues of inequality and social/environmental injustice (Dunaway, 2008, p. 69). As Rob Nixon (2014, p. 3) reminds us: "We may all be in the Anthropocene, but we're not all in it in the same way." The concept of the Anthropocene has taken hold in academic and popular culture (Schneiderman, 2015), but for those who fear a universalizing species narrative or Eurocentrically framed conversation, the term has given pause (see, for example, Demos, 2015, 2017; Haraway, 2016; Moore, 2015, among others). Bruno Latour (2013, n.p.) remarks that there is no "global globe," no unified container to hold the multitude of concerns that have assembled to replace the politics of nature. In response, then, we must start asking what Métis scholar Zoe Todd (2015, p. 244) asks: "Whose space is this and who is not here?"

The following pages invite a reconceptualization of this era, drawing inspiration from those working to imagine possible eras for the post-Anthropocene-imaginaries that do not deny the material histories and urgencies of the present. To cease our continued culture of environmental destruction, this paper argues for a reconceptualization of childhood and a transformation of childhood pedagogy. We begin by unpacking our figurative methodological approach. Subsequently, we probe the child-as-idea to examine how our conceptions of child ${ }^{3}$ are tied to understandings of nature, normativity, and futures premised on unsustainable and unjust expectations. We aim to challenge the complex and contradictory conceptions of child in the Anthropocene, the child-in-need-of-saving and the child-who-saves. Second, we probe conceptions of childhood pedagogy in order to shift long-held assumptions about nature, culture, and development to open unrealized possibilities and nonlinear trajectories. The resulting conception of a post-Anthropocene pedagogy resists certain discourses of responsibility and the linearity of growth to combat an over emphasis on predetermined ends conceived of in advance. This requires dismantling the allegedly clear boundaries between children and adults (Halberstam, 2011), unchaining normative connections between nature/culture and past/present/future to envision a pedagogy that obliges everybody to "take a detour, find a limit, lose our way," as Halberstam (2011, p. 121) advises. In other words, this post-Anthropocene pedagogy is not about what we do with/to children; rather, it hinges on (re)conceptualizing childhood and the associated norms we uphold or dismantle. It is about, as Hesoon Bai $(2009$, p. 147) explains, the logics with which we approach and enact whatever we are doing or not doing.

\section{Response-able Methods of Inquiry for "After" the Anthropocene}

We engage Isabelle Stengers' (2010) appeal to slow down by using a concept-as-method approach (St. Pierre, 2014 , p. 7) - that is, using concepts to slow down and reorient one's thinking. The Anthropocene, as a theoretical concept and as a representation of material urgencies, calls into question our most fundamental, "most cherished" structures: nature, time, reproduction, child. It brings to light what Kathryn Stockton (2009, p. 3) has described as "child-as-idea" signifying a host of contradictions, including reproductive futures, purity, revolution, incapacity, and becoming (Meiners, 2016). This paper argues that imagined environmental futures are fused with reproductive futures, intricately connected to heterofutures, based on underexamined assumptions that instrumentalize children 
toward the perpetuation of a selfsame future. We move from the concept-as-method, utilizing the concept of child in the Anthropocene, toward the figuration of child. ${ }^{4}$ We follow lines of interest (or, in Deleuze and Guattari's [1987] terms, lines of flight) rather than a territory partitioned into domains of study (Ingold, 2013) — drawing on interdisciplinary postcolonial, poststructural, and feminist understandings - taking us to figurations of child and the pedagogical implications therein. Following Donna Haraway, we utilize figurations-tropes or figurative metaphorical beings found within specific cultural traditions-to challenge existing taken-for-granted notions and habitual practices of thought. As opposed to concepts, figurations are where the imaginary meets the ordinary everyday; figurations are not "didactic illustrations, but rather material-semiotic nodes or knots in which diverse bodies and meaning co-shape one another" (Haraway, 2008, p. 4). Figurations have agency, history, and a life of their own.

The Anthropocene narrative has also spurred what Mark Grief, in his study The Age of the Crisis of Man (2015), calls a "discourse of responsibility" - which Purdy (2015, para. 13) defines as a strain of language that responds to geopolitical and environmental threats "with a blend of urgent language and concepts (or pseudo-concepts): responsibility, the fate of man." Yet, this responsibility is displaced onto future generations, which justifies actions that take responsibility from and for future generations. Thus, this paper is calling for a shift from an overemphasis on responsibility, to encourage response-ability. In Staying with the Trouble (2016), Haraway writes of responseability as a call to be responsive and directed toward justice and sustainable belonging. For many, the Anthropocene foreshadows the apocalypse: a fertile terrain to speculate about the future, propelling predictions of an emergency in the making. Contrasting this, we argue for an energizing urgency, which Haraway (2016, p. 37) contends has different temporalities than emergency, because it no longer connotes narratives of oncoming apocalypse or crisis. In an emergency, we rush to secure what we have deemed important: We aim to preserve our health, protect our property, determine safe passage for women and children. However, as Haraway $(2016$, p. 1) extrapolates, crisis "does not require a relationship to times called the future." Drawing on these understandings, we began to speculate a post-Anthropocene pedagogy, inspired by Haraway's notion of response-ability envisioned in her first explicit references to education, specifically in her book chapter "The Camille Stories." We hope to inspire, as Haraway (2016, p. 149) imagines, the circumstances under which children might foster the creation of complex subjectivities, become response-able multispecies collaborators, and initiate creative interdisciplinary practices aimed, not only at learning to live (and die) on a damaged planet, but at imagining and creating spaces of refuge for a future we cannot predict.

\section{Reproductive Futurism, Nature, and Child}

Children are enmeshed in our conceptions of time. Childhood (for adults) is at once future oriented and nostalgic, composed of imaginaries replete with underexamined assumptions, as adult anxieties_ontological insecuritiesfixate on creating determinable pasts and futures. Childhood is already an always-incomplete state (Castañeda, 2000). Children are perceived as not fully formed (pre-adults) outside the normative (adult) subject, which is perceived as complete and fixed. Its indeterminacy and plasticity, as Cindi Katz (2008, p. 7) explains, "opens it as a tremendously fertile figuration." To adults, children are repositories for adult fantasies (James et al., 1998; Steedman, 1985). Intensified via Anthropocene narratives of past, present, and future loss, adults cope with anxiety by "securing children's futures and producing perfect childhoods" (Katz, 2008, p. 6). Adult desires to protect children (from adulthood) or prepare children (for adulthood) employ notions of childhood as it should be to protect authentic nature in the lives of real children (Taylor, 2011). Yet, notions of nature are historically situated and unsettled.

By the end of the $18^{\text {th }}$ century, Rousseau had inspired the notion that children were representatives of a nature 
that was true, neutral, and universal: "the locus of essential goodness" (Taylor, 2011, p. 422). While pagans saw nature and the divine as united with the human and not necessarily as purely or innately good, the rise of urban society sparked new moral concerns which justified the separation of nature and the divine from humans, and reimagined nature as good, absolute, and pure (Bell, 2018). In contrast to Puritanical notions of children as sinful, for the Romantics, children offered a way back to this version of nature. Importantly, these influential Aristotelian and neo-Aristotelian perspectives saw children as qualitatively different from adults. According to Andrew Stables, differentiating children from adults shifted the way child is included, excluded, and implicated in the allencompassing categorical. Child came to mean not yet ready, or classified by an age when rights are not conferred. Within this distinction, as Stables (2008, p. 89) writes, child is understood to be "insufficiently developed for immersion in society, or (on the Romantic account, still popular among child-centred educators), as too good for it."

Throughout the $19^{\text {th }}$ and $20^{\text {th }}$ centuries, children became an important political site submerged within the term natural (Baker, 2001; Fausto-Sterling, 2000). The presumed separation between nature and culture reconfigured childhood as something that could be influenced by the outside environment. As Carolyn Merchant asserts, capitalism wrought newfound hopes of controlling destiny. Nature became conceived of in mechanistic terms, as resources to assemble and dominate (Merchant, 1980). Children represented another natural resource: empty vessels waiting to be filled, resilient yet innocent, like virgin soil yet to be corrupted, polluted, or sexualized. They were no longer smaller versions of adults, but future adults (Baker, 2001). Contemporary scholarship across disciplines has challenged notions of the natural as absolute, ongoing, and sublime, elucidating ways in which humans perceive the natural environment to erode the categorical distinction of nature/culture (see Cronon, 1995; Denevan, 1992). Yet, the legacies of complex and often contradictory beliefs remain. As questions of modification, labour, and activity collide with materiality, so too does the nature/culture divide, yet the Wilderness Debate Rages On (2008), and $19^{\text {th }}$ - and $20^{\text {th }}$-century notions of childhood linger in ideas of "human control over the future" (Baker, 2001, p. 64).

In the $21^{\text {st }}$ century, tethered to a future that we cannot predict, children are a resource to rescue us from the "future we (adults) threaten" by functioning as "the connection to nature we (adults) have corrupted" (Sheldon, 2016, p. 39). To envision (or make) an imagined future safe, children are figured as denizens of nature-and more so of naturalization-naturalizing futurism to provide an uncertain future with orderliness and meaning. Entangled with views of reproduction as the basis for life, children symbolize the natural order, normalizing (and regulating) the boundaries of personhood, as Judith Butler (2014, p. 426) reasons, "making persons according to abstract norms that at once condition and exceed the lives they make-and break."

Drawing on Lee Edelman's (2004) No Future: Queer Theory and the Death Drive and Rebekah Sheldon's (2016) The Child to Come: Life After the Human Catastrophe, this paper extends from Edelman's critique of the universal politics of "reproductive futurism" and Sheldon's analysis of child as a symbol (and tool) for humanity, framed as the answer to environmental catastrophe, the force that will "coordinate our safe passage into the future" (Sheldon, 2016, p. vii). Children, linked to species survival, might be conceived of as the mechanism to overcome planetary threat-a shift in perspective historically coincides with the Anthropocene's first articulation, as Sheldon (2016) asserts. Edelman's invective against heterofuturity highlights how imaginaries of the sacrosanct child disadvantage the queer, who are framed as antithetical to the essentialist assumptions upholding nature and children as natural and good. Edelman, as a queer person, situates himself outside such supposed social and biological norms upheld as "good," occupying an athwart (Probyn, 2016) vantage point to perceive the political processes that beguile children into maintaining social norms. Thus, while Edelman rejects this figuration of child, he may see himself aligned with actual children who are also not able to choose for themselves what they represent. For Edelman, 
futurism itself - the drive to guarantee that our social reality will persist even after we're gone-is the underlying culprit aiming to maintain civilization $a s$ is.

\section{The Future Is Not for Everyone}

Child (like "science" or "nature") is widely understood as "race neutral," concealing how contemporary configurations of childhood are highly racialized. As Robin Bernstein's Racial Innocence: Performing American Childhood from Slavery to Civil Rights (2011) details, racialized childhood was central to the $16^{\text {th }}$ - to $19^{\text {th }}$-century movements that shaped representational democracy in the United States. Child, defined as unable to consent in relation to the rational adult male, came to represent everything that should prohibit a subject from citizenship (Duane, 2010). During this time, child became the embodiment of innocence, distinctly envisioned as white: As Robin Bernstein (2011) writes, "The doctrine of original sin receded, replaced by a doctrine of original innocence" (p. 4). Innocence negates experience, while a figure free of a past undergirds educable heterofutures (Stockton, 2009). Likewise, to sustain a future predicated on the white, able-bodied man of humanism (Braidotti, 2013), environmental futurism often relies on imaginary pasts filled with pure and pristine conceptions of nature, displacing untidy or disordered histories that might conflict with maintaining (Western) civilization. Yet, the United States was not an untouched wilderness, but the result of a violent restructuring of indigenous ways of life (Rifkin, 2011). Natives were assessed as childlike (i.e., incapable and underdeveloped) to justify the United States as "parent" nation in order to normalize, naturalize, and enable claims on land, property, and inheritance (Smith, 2010; Zaborskis, 2016). Moreover, compulsory colonial models of kinship dismantled preexisting collective decision making and multispecies relationships to serve white settler communities. Indeed, the United States conceptualizes and partitions resources to maintain white heteronormative futures. As a white privilege, innocence is systemically denied to brown bodies (Meiners, 2016). This structure guarantees failure of nonwhite bodies to become part of a desired and/or imposed reproductive future and to transition into civic and economic personhood: to vote, own a home, etc. As Jose Muños (2009) notes, if childhood is countered by an adulthood of white futurity, many children of colour are never able to "grow up."

Goaded by increasing environmentalist calls to forestall catastrophe for the sake of the children, child in the Anthropocene relies on prescriptive, unsustainable, and unjust ways of relating to the future. Placed within white supremacist colonial ambitions, reproductive futurism preserves exclusionary ideologies alongside extractive and propriety relationships to the land and one another. Anchored to notions such as "generational shifts" (e.g., father to son), reproductive futurism maintains norms organized around historical (settler) conceptions of progress and change. Adults instill children with stability to carry them into the future through deep-rooted (hetero)normative and racialized logics. As Haraway $(2016$, p. 1) describes, the present and past are cleared to make futures for coming generations, drawing lines of flight through settler colonialisms' temporal elimination tied to relations of erasure between the past and future, employing what Eve Tuck and Ruben Gaztambide-Fernandez (2013, p. 73) call the "curriculum project of replacement." Tuck and Gaztambide-Fernandez draw on Andrew Baldwin to illustrate how futurity relates to the ways that the "future is rendered knowable through specific practices (i.e., calculation, imagination, and performance) and, in turn, intervenes upon the present through three anticipatory logics (i.e., pre-caution, pre-emption and preparedness)" (Baldwin, 2012, as cited in Tuck \& Gaztambide-Fernandez, 2013, p. $80)$.

\section{Growing Futures}

In the field of education, particularly early childhood and environmental education, the garden as a metaphor for growth has been widely and historically used to foster practices that manage, nurture, cultivate, tend, and plot 
children's growth into the future. While it is not new to compare children to plants, as Rousseau did, emergent critiques link plant/animal control with human control (Bonnett, 2009) to demonstrate how the desire for "perfection in gardens and people [is] rooted in an ongoing struggle against 'difference"' (Subramaniam, 2014, p. 6). Gardens are employed to maintain civilization: citizens grow food to prepare for survival; national parks uphold empire; wilderness is preserved on behalf of Protestant notions of the pure and pristine; and public and private lawns regulate decency and decorum (see Burns, 2009; Cronon, 1995; Denevan, 1992; Robbins, 2007). As Julia Ostertag (2015) detailed, there has been a long history of gardens being used in colonial, military, and political regimes, including in Nazi Germany, the Canadian residential schooling systems, and so-called victory gardens grown in many countries during World War I and II (also called "war gardens" or "food gardens for defence"). Natasha Myers (2016), through her research on gardens and plant/people involution, discusses how the aesthetics and politics of gardens perpetuates the extractive and colonial logics of capitalism and fosters apocalyptic imaginaries. While there is much to learn from gardening-relating to the material and more-than-human world, including ways to encourage anticolonial resonances (Nxumalo, 2016) and the open embrace of caring, aesthetics, and learning by doing - the history of gardens is tied to domination over land/place/people and an erasure of nomadic/alternative practices.

Landscapes can become the catalyst for activities, challenging the dominant perception that adults must predetermine how and what materials inform learning. The Children's Museum in Santa Fe, New Mexico, has a

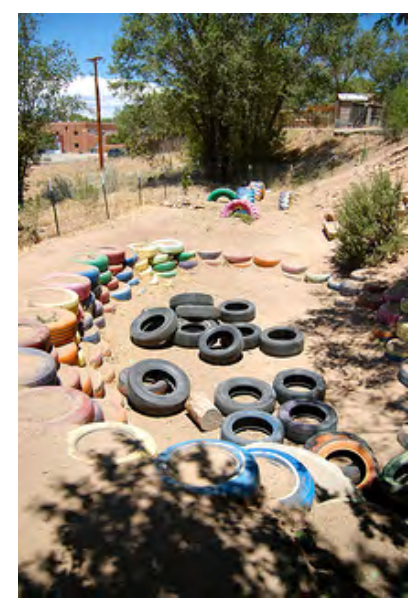
beautifully designed garden that includes a tree house and an interactive compost heap. A large open pit was located at the edge of the garden. It was full of spare construction parts used around the property, including a pile of spare tires. Several years ago, as the interim director of an outdoor summer camp for children 5-11, author Alexandra Lakind observed how children were drawn to the pit. They would run directly to the pit, bypassing the garden entirely. They loved to bounce tires and watch them tumble. The children were not predesigning a space for play; they were responding to one another and the materials around them. Soon games, characters, and collaborative roles took shape. Intuitively, the children started to answer questions: How tall might a stack of tires get? Could you arrange enough tires to jump along so that you didn't sink into the imaginary ocean? Rather than responding by closing the pit off to the public, the museum embraced the newfound play space and stepped in to support the site. With supervision, children painted the tires, built tunnels encased with adobe, and created paths to carry tires uphill and roll them down.

These designs were created in conversation with the tires, the dirt, and the steep inclines that surrounded the site. This mode of creation as reciprocal and responsive invited objects and histories to the fore. It worked against methods of design that project future (safe and humancentric) imaginaries onto the landscape. The inclines contrasted flattened sites that clear away their past and present sedimented materializations to build projects for a predestined future. The gardens were landscaped as part of a forward-thinking, progressive curriculum. A carefully tended space to fuel development-what Myers (2016) would describe as designing for the Anthropocene-a space that hides the aestheticized histories of colonialism, labour, and capital. The garden was constructed as a playground, thought through in terms of safety and developmental needs-threats already managed, skills already envisioned. A natural and safe space for children to learn and grow. Yet, as we have already elaborated, perceived risks and perceived outcomes are caught up in predetermined hypotheses. At the museum, such predetermined (predesigned) blueprints were deprivileged, as were the naturalized normative conceptions of beauty. Instead, museum staff valued the aesthetic potential of the tires and the relational activities (games) that emerged from the landscape. The museum took their cue from children and were unconcerned that the garden often remained 
abandoned because of the lure of the tire pit. "Wild" connotes something lacking direction, unruly (Bekoff, 2014). Yet in this case, by following the interests of the children, a process of rewilding was created; human intervention restored spontaneity emergent from ecological systems (Monbiot, 2013). It entailed the abandonment of conventional justifications that educators place on top of these interactions. This outcome did more than simply train children in engineering, present a safe place to play, or become an example of a collaborative effort. It was a project done in the direction of interest, with materials deemed worthy by the children themselves. The museum didn't decide what to share with children, but rather allowed children to come to their own conclusions, sharing them with the museum.

\section{A Post-Anthropocene Pedagogy}

In a pedagogy for the post-Anthropocene, we reconfigure what is considered under threat, challenging what dictates "emergency" response. In the Unites States, the educational system collapses future threats into present configurations designed to manage, measure, and anticipate risk. Indeed, we manage concerns that America is "falling behind" with STEM education; we create standardized strategies for kindergarten readiness; we implement patriotism by requiring students to repeat The Pledge of Allegiance. ${ }^{5}$ In these systems, children become increasingly oriented toward the future, intertwined with the reproduction of social norms. Children are presumed to need training to sync with adult temporal logics. Pedagogies of linear lines, to borrow from Tim Ingold (2007), convert "paths along which life is lived into boundaries in which it is contained" (p. 2). Education becomes a cypher for planning, supervision, assessment, and evaluation of predefined objectives (Dahlberg, Moss, \& Pence, 2007; Lenz Taguchi, 2009; Masny \& Cole, 2009). Time and space are fixed as we teach children to become the adults we want them to be: to marry and reproduce, to attain careers and enlightenment, acquire behaviours, write thank-you cards, recycle, perform chivalry. We educate for a better tomorrow. We do it for the children, for those who will supersede us, overshadowing them with what we want them to be. Toward this end, "teaching" is captured by time: The present becomes a mirage of a fantasized past and dream of a future by sentimentalizing stasis. A pedagogy for the post-Anthropocene does not deny this worrisome future, nor the resultant affects. Rather, it aims to unsettle the constraints placed on children to fulfill, preserve, or save futures they have yet to name, imagine, and create.

The post-Anthropocene rests on a process of unlearning practices of methodological individualism to relearn practices of collective development. We are not managers, engineers, or stewards of a passive earth, nor are we the unwanted detritus of a morally righteous planet. We are entangled in an assemblage of collective vulnerability. To reorient toward a post-Anthropocene pedagogy, embracing the fluidity of naturecultures (see Haraway, 2013) can help problematize humanism's binary divides, such as nature/culture, child/adult, and theory/practice, to trouble child subjectivity, queering the nature of identity and individual existence (Murris, 2017). Instead of being answerable to our norms and pregiven codes, a pedagogy for the post-Anthropocene encourages the ability to answer, openly and in accordance with the complexities and indeterminacies of unpredictable affective conditions. In other words, it is a situated practice of cocreation that invites new ways of relating, a vision of environmental education where, as Lucie Sauvé (2009, p. 325) writes, "being here" is situated "now." This resistance to futurism and a predetermined future is not to follow Edelman down the pessimistic path of "No Future," but to avoid preemptively orienting toward it, and to avoid "the tyranny of a life already represented as 'is"' (Rotas \& Springgay 2013, p. 6). The key, pedagogically, is to stay open "to the surprising possibilities that emerge from the constant, undetermined nature of reality" (Pacini-Ketchabaw \& Nxumalo, 2013, p. 19). The shapes of desire can be infinite, but if one plot dominates the scenes of proper fantasy, children lose agency to follow their desires and orient toward something they find meaningful. This pedagogy is not a disavowal of the future, but of future-orientations that negate children as bearers of their own experience and agents of their own purpose. 
Emily Beausoleil (2015) succinctly explains the difference between a responsibility embedded in our punitive approaches to accountability and a responsibility of responsiveness-response-ability. Rather than a system wherein people are "held to account" and assessed in relation to fixed terms, response-ability is "enacted in the pulse and pause of attentiveness" (p. 2, emphasis in original). This is about looking to the future without having an answer of what it holds. As Karen Barad (2012, p. 69) says, "responsibility, then, is a matter of the ability to respond"; it is about correspondence with the world: a model of seeing into the future by looking where you are going (Ingold, 2013). Haraway (2015, p. 257) describes response-ability as "that cultivation through which we render each other capable." To render children able, we need to abandon the tropes of "mother nature" needing protection/taming, corresponding to justifications of control over children conceived of as innocent, weak, unpredictable, and/or undisciplined. Sianne Ngai (2012) asks if "cute" is a way to aestheticize powerlessness. The cute object is most fully itself when weak and in need of protection, and is often politicized through propaganda regimes-the helpless starving child, the vulnerable polar bear cub, and the clumsy baby penguin. To render cute as capable, instead of being infantilized (drawing on conceptions of infants and baby animals as incapable beings), we might instead intimate ongoing care and learning together.

In a pedagogy for the post-Anthropocene, preparedness is not the concern; rather the concern is the rigid and fixed way in which we prepare, and for whom we prepare, and toward what end. A post-Anthropocene pedagogy invites postcolonial and postdevelopmental perspectives to reject universal stages of childhood and examine how the effects of colonization are deeply intertwined with our understandings of nature and what's "natural" (Cannella \& Viruru, 2004; Pacini-Ketchabaw, 2014). In the pedagogy we're proposing, predictable adulthoods are not the goal, regardless of the approach. Children, whether managed or left alone, refigured for the post-Anthropocene, become response-able collaborators toward living (and dying) on a damaged planet. Once again, this is a reminder to learn from children, whose everyday life is, as $\operatorname{Katz}(2008$, p. 9) describes, "suffused with social relations that can exceed commodification, evade colonization, and recreate the means of existence and subjectivity in new registers." We, like Edelman, make a firm distinction between philanthropy and love, where love is not driven by obligation. We are not obliged to "help" children, but rather to codevise alternative life narratives and new forms of kinship. In the post-Anthropocene, the emphasis is on relationships of reciprocal care, always more than one way, and never self-sufficient, because as Rosi Braidotti (2006, p. 93, emphasis in original) reminds us, "We' are indeed in this together."

\section{Speculative Imaginaries for the Post-Anthropocene}

Welcome to the Anthropocene closes with a warning: "We must find a safe operating space for humanity for the sake of future generations." The film's oral and visual narrative deploys a performative imagery of earth that reduces the complexity and urgency of our present moment. The earth appears whole, still, and isolated, making life itself seem fragile, vulnerable, and in need of protection. In this setting, children are reasoned in relation to the future and depicted as the basis for hope, a symbol for humanity. As logical necessities to extend species survival, children (and their reproduction), when conceived (theoretically), become a focal point for planetary futurity. As the film continues, the narrator states: "We are the first generation to realize this new responsibility" (Gaffney \& PharandDeschenes, 2012, n.p.). It seems that the Anthropocene, following McKenzie Wark (2016), is a term that arrived too early and a warning that arrived too late. Following Myers (2016), we believe we need not wait for the ledge for the after:

The "after" in this formation does not circumscribe a time-bound era, some later epoch or period on the other side of apocalypse or ruination. Rather the "after" [or "post"] marks what might come in the wake of Anthropocene thinking, once this concept has been set in motion. (p. 5) 
This paper engages with thought and theory after the concept of the Anthropocene has done its job of troubling the waters. In the wake of the Anthropocene, we imagine and foster response-ability, encouraging exploration, a chance to "venture off the beaten path to meet the unexpected, non-natal kin, and to strike up conversations, to pose and respond to interesting questions, to propose together something unanticipated" (Haraway, 2016, p. 130). This is an ethical refiguring, not about a right way, but about-as Barad (2012, p. 69) extrapolates_-"accountability for the lively relationalities of becoming, of which we are part." For, to make a livable world, a backward glance at human impact on earth and a hopeful glance toward future generations is not enough. We need new imaginaries and new collective practices.

We subscribe to an energizing urgency, envisioning a pedagogy that obliges everybody to venture off the beaten path to meet the unexpected. In other words, this post-Anthropocene pedagogy is not about what we do with/to children. Rather, it hinges on (re)conceptualizing childhood and the associated norms we uphold or dismantle. We need alternative imaginaries for the near term (i.e., within the next 100-200 years), when humanity will be in the midst of dealing with the effects of climate change and the struggle against capitalism, instead of the postapocalyptic "doom-and-gloom" stories that don't include imaginaries for grappling with these crises. Haraway (2011) illustrates such an imaginary in her SF6 book chapter "The Camille Stories," through which she explores "oddkin and multispecies reproductive justice." The Camille Stories take up the task of addressing multispecies environmental and reproductive justice, particularly the challenge of reducing human population levels. She aims to do this without perpetuating the legacies of Malthusian and neo-Darwinian stances-regulation of sexuality through perceived evolutionary truth and overpopulation seen in terms of socio-political conditions-which remain problematic (Gosine, 2010). In the name of population control, people in the United States (particularly poor, disabled, and/or nonwhite women) have been sterilized and denied reproductive and parenting rights (see Roberts, 1997). Furthermore, developmental logic positioning the Global South as immature has storied overpopulation as a problem caused by people in countries that have yet to industrialize who might "push us over the brink" (Sturgeon, 2010, p. 124; Gosine, 2005). Both in the United States and abroad, reproductive nonwhite sex is suspect, embroiled in a complex dance around environmental concerns and evolutionary narratives. Haraway does not propose answers, but attempts to address this taboo territory by imagining one particular possible worlding. The story traces five Camilles from 2025, when human populations reach ten billion, to 2425, when human populations have dropped to three billion and biodiversity on earth has been reduced by half. Each new child born is paired with a species symbiont and genetically modified to take on biological aspects/features of that species.

Haraway's (2016, p. 6) call to address the "Great Acceleration of human numbers," when combined with multispecies reproductive justice, could become a catalyst to reenvision childhood (and life) outside of a reproductive futurism tied to human exceptionalism and support forms of extended kinship networks that care for humans and nonhumans alike. It can resist what Mortimer-Sandilands and Erickson (2010) see as the anti-child stance of mainstream environmentalism that still privileges Western modes and forms of (re)production and family as normal, natural, and divine (Sturgeon, 2010). The Camille stories function as string figure plots, an elaborate storyboard, a creative provocation for others to develop their own Camille stories, contributing to the collective task of imagining practices of partial flourishing on a damaged planet, practices that involve what Deborah Bird Rose (2014) calls "taking care of country" — not of an abstract future but of what Haraway describes as the "thick present" - a practice of being accountable to the past in order to find ways of living together in partial flourishing and partial healing now. The task is to learn to take care of times that don't work as past-present-future but require accountability, response-ability, and creative speculation. 


\section{References}

Bai, H. (2009) Reanimating the universe. In M. McKenzie, P. Hart, H. Bai, \& B. Jickling (Eds.) Fields of green: Restorying culture, environment, and education (pp. 135-153). New York, NY: Hampton Press.

Baker, B. (2001). In perpetual motion: Theories of power, educational history, and the child. New York, NY: Peter Lang.

Barad, K. (2012). Interview with Karen Barad. In R. Dolphijn \& I. van der Tuin (Eds.), New materialisms: Interviews and cartographies (pp. 48-71). Ann Arbor, MI: Open Humanities Press.

Beausoleil, E. (2015). Embodying an ethics of response-ability. Borderlands, 14(2), 1-16. Retrieved from http://www.borderlands.net.au/ vol14no2_2015/beausoleil_embodying.pdf

Bekoff, M. (2014). Rewilding our hearts: Building pathways of compassion and coexistence. Novato, CA: New World Library.

Bell, M. (2018). City of the good: Nature, religion, and the ancient search for what is right. Princeton, NJ: Princeton University Press.

Bennett, J. (2010). Vibrant matter: A political ecology of things. Durham, NC: Duke University Press.

Berlant, L. (2014). Love. In C. R. Stimpson \& G. Herdt (Eds.), Critical terms for the study of gender (pp. 250-270). Chicago, IL: University of Chicago Press.

Bernstein, R. (2011). Racial innocence: Performing American childhood from slavery to civil rights. New York: New York University Press.

Bonnett, M. (2009). Education, sustainability, and the metaphysics of nature. In M. McKenzie, P. Hard, H. Bai, \& B. Jickling (Eds.), Fields of green: Restorying culture, environment, and education (pp. 177-187). New York, NY: Hampton Press.

Braidotti, R. (2006). Transpositions: On nomadic ethics. Cambridge, UK: Polity Press.

Braidotti, R. (2013). The posthuman. Cambridge, UK: Polity Press.

Burns, K. (Director). (2009). The national parks: America's best idea. Washington, DC: Florentine Films. Retrieved from http://www.pbs. org/nationalparks/about

Butler, J. (2014). Regulation. In C. R. Stimpson \& G. Herdt (Eds.), Critical terms for the study of gender (pp. 411-427). Chicago, IL: University of Chicago Press.

Butler, J. (2015). Notes towards a performative theory of assembly. Cambridge, MA: Harvard University Press.

Cannella, G., \& Viruru, R. (2004). Childhood and postcolonialization: Power, education, and contemporary practice. New York, NY: Routledge.

Carstens, D. (2016). The Anthropocene crisis and higher education: A fundamental shift. South African Journal of Higher Education, 30(3), 255-273. doi: 10.20853/30-3-650

Castañeda, C. (2000). Figurations: Child, bodies, worlds. Durham, NC: Duke University Press.

Cronon, W. (1995). The trouble with wilderness, or, getting back to the wrong nature. In W. Cronon (Ed.), Uncommon ground: Rethinking the human place in nature. New York, NY: W. W. Norton \& Co.

Dahlberg, G., Moss, P., \& Pence, A. (2007). Beyond quality in early childhood education and care: Postmodern perspectives (2 $2^{\text {nd }}$ ed.). London, UK: Falmer Press.

Deleuze, G., \& Guattari, F. (1987). A thousand plateaus: Capitalism and schizophrenia (B. Massumi, Trans.). Minneapolis: University of Minnesota Press.

Demos, T. J. (2015, May 5). Welcome to the Anthropocene [blog post]. Retrieved from https://www.fotomuseum.ch/en/explore/stillsearching/articles/27011

Demos, T. J. (2017). Against the Anthropocene: Visual culture and environment today. Berlin, Germany: Sternberg Press. 
Denevan, W. (1992). The pristine myth: The landscape of the Americas in 1942. Annals of the Association of American Geographers, 82(3), 369-385. Retrieved from http://www.uvm.edu/ cemorse/geography050/Denevan,\%20Pristine\%20Myth.pdf

Duane, A. (2010). Suffering childhood in early America: Violence, race, and the making of the child victim. Athens: University of Georgia Press.

Dunaway, F. (2008). Gas masks, Pogo, and the ecological Indian: Earth Day and the visual politics of American environmentalism. American Quarterly, 60(1), 67-99.

Edelman, L. (2004). No future: Queer theory and the death drive. Durham, NC: Duke University Press.

Fausto-Sterling, A. (2000). Sexing the body: Gender politics and the construction of sexuality. New York, NY: Basic Books.

Gaffney, O., \& Pharand-Deschenes, F. (Writers). (2012). Welcome to the Anthropocene. Big World Small Planet. Retrieved from http:// anthropocene.info/short-films.php

Gosine, A. (2005). Dying planet, deadly people: "Race”-Sex anxieties and alternative globalizations. Social Justice, 32(4), 69-86.

Gosine, A. (2010). Non-white reproduction and same-sex eroticism: Queer acts against nature. In C. Mortimer-Sandilands \& B. Erickson (Eds.), Queer ecologies: Sex, nature, politics, and desire (pp. 149-172). Bloomington: Indiana University Press.

Greenwood, D. (2014). Culture, environment, and education in the Anthropocene. In M. P. Mueller, D. J. Tippins, \& A. J. Stewart (Eds.), Assessing schools for generation $R$ (responsibility): A guide for legislation and school policy in science education (pp. 279-292). Dordrecht, The Netherlands: Springer. doi: 10.1007/978-94-007-2748-9_20

Greif, M. (2015). The age of the crisis of man: Thought and fiction in America, 1933-1973. Princeton, NJ: Princeton University Press.

Halberstam, J. (2011). The queer art of failure. Durham, NC: Duke University Press.

Haraway, D. (2004). The Haraway reader. London, UK: Routledge.

Haraway, D. (2008). When species meet. Minneapolis: University of Minnesota Press.

Haraway, D. (2013). Simians, cyborgs, and women: The reinvention of nature. London, UK: Routledge.

Haraway, D. (2014). Anthropocene, Capitalocene, Chthulucene: Staying with the trouble. Anthropocene: Arts of Living on a damaged planet. Retrieved from http://opentranscripts.org/transcript/anthropocene-capitalocene-chthulucene

Haraway, D. (2015). Anthropocene, Capitalocene, Chthulhucene: Donna Haraway in conversation with Martha Kenney. In H. Davis \& E. Turpin (Eds.), Art in the Anthropocene: Encounters among aesthetics, politics, environments and epistemologies (pp. 255-270). London, UK: Open Humanities Press.

Haraway, D. (2016). Staying with the trouble. Durham, NC: Duke University Press.

Haraway, D., Ishikawa, N., Gilbert, S. F., Olwig, K., Tsing, A. L., \& Bubandt, N. (2016). Anthropologists are talking-About the Anthropocene. Ethnos, 81(3), 535-564.

Ingold, T. (2013). Making: Anthropology, archaeology, art, and architecture. London, UK: Routledge.

James, A., Jenks, C., \& Prout, A. (1998). Theorizing childhood. Cambridge, UK: Polity Press.

Katz, C. (2008). Childhood as spectacle: Relays of anxiety and the reconfiguration of the child. Cultural Geographies, 15(1), 5-17.

Kirksey, E. (Ed.). (2014). The multispecies salon. Durham, NC: Duke University Press.

Latour, B. (2013, March 1). The Anthropocene and the destruction of the image of the globe. In Facing Gaia: A new enquiry into natural religion. Gifford Lecture Series. Retrieved from https://www.giffordlectures.org/lectures/facing-gaia-new-enquiry-naturalreligion

Lenz Taguchi, H. (2009). Going beyond the theory/practice divide in early childhood education: Introducing an intra-active pedagogy. 
London, UK: Routledge.

Malm, A. (2015, March 30). The Anthropocene myth: Blaming all of humanity for climate change lets capitalism off the hook. Jacobin. Retrieved from https://www.jacobinmag.com/2015/03/anthropocene-capitalism-climate-change

Masny, D., \& Cole, D. R. (2009). Multiple literacies theory. Rotterdam, The Netherlands: Sense.

Meiners, E. (2016). For the children? Protecting innocence in a carceral state. Minneapolis: University of Minnesota Press.

Merchant, C. (1980). The death of nature: Women, ecology, and the scientific revolution. New York, NY: Harper \& Row.

Monbiot, G. (2013). Feral: Searching for enchantment on the frontiers of rewilding. London, UK: Allen Lane.

Moore, J. (2013, July 4). Anthropocene, Capitalocene, and the myth of industrialization II [blog post]. Retrieved from https://jasonwmoore. wordpress.com/2013/07/04/anthropocene-capitalocene-the-myth-of-industrialization-ii/

Moore, J. (2015). Capitalism in the web of life: Ecology and the accumulation. Brooklyn, NY: Verso.

Mortimer-Sandilands, C., \& Erickson, B. (2010) Queer ecologies: Sex, nature, politics, and desire. Bloomington: Indiana University Press.

Muñoz, J. (2009). Cruising utopia: The then and there of queer futurity. New York: NYU Press.

Murris, K. (2017): Reading two rhizomatic pedagogies diffractively through one another: A Reggio-inspired philosophy with children for the postdevelopmental child. Pedagogy, Culture, \& Society, 25(4), 531-550. doi: 10.1080/14681366.2017.1286681

Myers, N. (2016). Edenic apocalypse to gardens against Eden: Plants and people in and after the Anthropocene [draft chapter to be published in February 2019 in K. Hetherington (Ed.), Infrastructure, environment, and life in the Anthropocene. Durham, NC: Duke University Press]. Retrieved from https://www.academia.edu/25030679/From_Edenic_Apocalypse_to_Gardens_ Against_Eden_Plants_and_People_in_and_after_the_Anthropocene

Nagai, S. (2012). Our aesthetic categories: Zany, cute, interesting. Cambridge, MA: Harvard University Press.

Nelson, M., \& Callicott, J. (Eds.), (2008). The wilderness debate rages on: Continuing the great new wilderness debate. Athens: University of Georgia Press.

Nixon, R. (2014, November 6). The Anthropocene: Promise and pitfalls of an epochal idea. Edge Effects. Retrieved from http://edgeeffects. net/anthropocene-promise-and-pitfalls

Norgaard, R. B. (2013). The Econocene and the delta. San Francisco Estuary and Watershed Science, 11(3), 1-5.

Nxumalo, F. (2016). Touching place in childhood studies: Situated encounters with a community garden. In H. Scott-Myhre, V. PaciniKetchabaw, \& K. Scott-Myhre (Eds.), Youth work, early education, and psychology: Liminal encounters (pp. 131-258). New York, NY: Palgrave Macmillan.

Ostertag, J. K. (2015). School gardening, teaching, and a pedagogy of enclosures: Threads of an arts-based métissage (Doctoral dissertation). Retrieved from http://hdl.handle.net/2429/52994

Pacini-Ketchabaw, V. (2014). Postcolonial and anti-racist approaches to understanding play. In L. Booker, M. Blaise, \& S. Edwards (Eds.), The SAGE handbook of play and learning in early childhood (pp. 67-78). London, UK: SAGE.

Pacini-Ketchabaw, V., \& Nxumalo. F. (2013). Regenerating research partnerships in early childhood education: A non-idealized version. In J. Duncan \& L. Conner (Eds.), Research partnerships in early childhood education: Teachers and researchers in collaboration (pp. 11-26). New York, NY: Palgrave Macmillan.

Payne, P. (2016). What next? Post-critical materialisms in environmental education. The Journal of Environmental Education, 47(2), 169-178. doi: 10.1080/00958964.2015.1127201

Payne, P. (2017). Early years education in the Anthropocene: An ecophenomenology of children's experience. In M. Fleer \& B. van Oers (Eds.), International handbook on early childhood education (pp. 117-162). New York, NY: Springer. 
Probyn, E. (2016). Eating the ocean. Durham, NC: Duke University Press.

Purdy, J. (2015). Anthropocene fever. Aeon, Harvard University Press. Retrieved from https://aeon.co/essays/should-we-be-suspiciousof-the-anthropocene-idea

Rifkin, M. (2011). When did Indians become straight? Kinship, the history of sexuality, and native sovereignty. New York, NY: Oxford University Press.

Robbins, P. (2007). Lawn people: How grasses, weeds, and chemicals make us who we are. Philadelphia, PA: Temple University Press.

Roberts, D. (1997). Killing the black body: Race, reproduction, and the meaning of liberty. New York, NY: Vintage Books.

Rose, D. B. (2014, November 19). Flying foxes and the G20 [blog post]. Love at the Edge of Extinction. Retrieved from http://deborahbirdrose. com/2014/11/19/flying-foxes-and-the-g20

Rotas, N., \& Springgay, S. (2013). "You go to my head": Art, pedagogy, and a "politics-to-come." Pedagogies: An International Journal, 8(3), 278-290. doi: 10.1080/1554480X.2013.794917

Sables, A. (2008). Childhood and the philosophy of education: An anti-Aristotelian perspective. New York, NY: Continuum.

Sauvé, L. (2009). Being here together. In M. McKenzie, P. Hart, H. Bai, \& B. Jickling (Eds.), Fields of green: Restorying culture, environment, and education (pp. 325-337). New York, NY: Hampton Press.

Schneiderman, J. (2015). Naming the Anthropocene. philoSOPHIA, 5(2), 179-201.

Sheldon, R. (2016). The child to come: Life after human catastrophe. Minneapolis: University of Minnesota Press.

Smith, A. (2010). Queer theory and Native studies: The heteronormativity of settler colonialism. Journal of Lesbian and Gay Studies, 16(1-2), 41-68.

Snaza, N., Sonu, D. Truman, S., \& Zaliwska, Z. (2016). Pedagogical matters: New materialisms and curriculum studies. New York, NY: Peter Lang.

Steedman, C. Urwin, C., \& Walkerdine, V. (1985). Language, gender, and childhood. London, UK: Routledge.

Steinmetz, G. (2005). The epistemological unconscious of U.S. sociology and the transition to post-Fordism: The case of historical sociology. In J. Adams, E. S. Clemens, \& A. Shola Orloff (Eds.), Remaking modernity: Politics, history, sociology (pp.109-175). Durham, NC: Duke University Press.

Stengers, I. (2010). Cosmopolitics. Minneapolis: University of Minnesota Press.

St. Pierre, E. (2014). A brief and personal history of post qualitative research toward "post inquiry." Journal of Curriculum Theorizing, $30(2), 2-19$.

St. Pierre, E., Jackson, A. Y., \& Mazzei, L. (2016). New empiricisms and new materialisms: Conditions for new inquiry. Cultural Studies $\bigotimes$ Critical Methodologies, 16(2), 99-110. doi: 10.1177/1532708616638694

St. Pierre, E., \& Pillow, W. (2000). Working the ruins: Feminist poststructural theory and methods in education. New York, NY: Routledge.

Stockton, K. B. (2009). The queer child, or growing sideways in the twentieth century. Durham, NC: Duke University Press.

Sturgeon, N. (2010). Penguin family values: The nature of planetary environmental reproductive justice. In C. Mortimer-Sandilands \& B. Erickson (Eds.), Queer ecologies: Sex, nature, politics, and desire (pp. 102-133). Bloomington: Indiana University Press.

Subramaniam, B. (2014). The aliens in our midst: Managing our ecosystems. In D. Kleinman, K. Cloud-Hansen, \& J. Handelsman (Eds.), Controversies in science and technology. Cambridge, UK: Oxford University Press.

Taylor, A. (2011). Reconceptualizing the "nature" of childhood. Childhood, 18(4), 420-433.

Todd, Z. (2015). Indigenizing the Anthropocene. In H. Davis \& E. Turpin (Eds.), Art in the Anthropocene: Encounters among aesthetics, 
politics, environments and epistemologies (pp. 241-254). London, UK: Open Humanities Press.

Tsing, A. L. (2015). The mushroom at the end of the world: On the possibility of life in capitalist ruins. Princeton, NJ: Princeton University Press.

Tsing, A. L., Swanson, H., Gan, E., \& Bubandt, N. (Eds.). (2017). Arts of living on a damaged planet. Minneapolis: University of Minnesota Press.

Tuck, E., \& Gaztambide-Fernandez, R. (2013). Curriculum, replacement, and settler futurity. Journal of Curriculum Theorizing, 29(1), $72--89$.

Wagler, R. (2011). The Anthropocene mass extinction: An emerging curriculum theme for science educators. The American Biology Teacher, 73(2), 78-83. doi: 10.1525/abt.2011.73.2.5

Wark, M. (2015). Molecular red: Theory for the Anthropocene. Brooklyn, NY: Verso.

Weston, K. (1998). Long slow burn: Sexuality and social science. New York, NY: Routledge.

Zaborskis, M. (2016). Sexual orphaning: Native queer childhood. Journal of Lesbian and Gay Studies, 22(4), 605-628.

\section{(Endnotes)}

1 The film Welcome to the Anthropocene (2012) was commissioned by the Planet Under Pressure conference. The film is "part of the world's first educational web portal on the Anthropocene," developed and sponsored by anthropocene.info.

This visual shift is also described by T. J. Demos (2015) in his blog post "Welcome to the Anthropocene!" in which he describes how the film "offers an authoritative voice-over commentary that narrates a shifting data visualization of the globe, showing schematic networks of light trajectories that reference energy, transportation and communication systems" (https://www. fotomuseum.ch/en/explore/still-searching/articles/27011_welcome_to_the_anthropocene). The schematic network image of the globe used in the video is also the same as the image Demos uses on the cover of his new book Against the Anthropocene: Visual Culture and Environment Today (2017).

Following Murris (2017, p. 16) we have written "child" as opposed to "the child" to write about the concept of child while distancing ourselves from writing about the child as a contained "bounded entity in space and time with a set of essential and universal characteristics (often resulting in the marginalization of children).”

$4 \quad$ Figurations, a literary tool introduced/used by Donna Haraway, are tropes or figurative metaphorical beings found within specific cultural traditions. Haraway $(2004,2008 \mathrm{a})$ creates new powerful figurations (e.g., cyborg, dogs, OncoMouse $\mathrm{e}^{\mathrm{m}}$, and other companion species) to work/think/play with in order to challenge existing taken-for-granted notions and habitual practices of thought. This conception of child we critique in this article is Western, drawing on culturally situated tropes that do not represent the multiplicity of notions within and across geographical and temporal boundaries. For Haraway (2004, 2008a), figurations are where the imaginary meets the ordinary everyday.

5 In 1892, the pledge was written with the hope that it could be used by citizens in any country. In 1923, "the Flag of the United States of America" was added. In 1954, in response to the threat of communism, the words "under God" were added. Public schools require children to stand, face the flag, and put their hand over their heart to recite "I pledge allegiance to the flag of the United States of America, and to the republic for which it stands, one nation under God, indivisible, with liberty and justice for all."

6 As Haraway (2011, p. 12) writes, "SF is that potent material-semiotic sign for the riches of speculative fabulation, speculative feminism, science fiction, speculative fiction, science fact, science fantasy_and, I suggest, string figures." Haraway playfully uses multiple meanings of SF games to dismantle the fact/fiction binary, drawing connections through the various practices of creating and imagining reality/stories/worlds, "practices of scholarship, relaying, thinking with, [and] becoming with" (Haraway, 2011, p. 15). Haraway (2011, p. 12) adds: "In looping threads and relays of patterning, this SF practice is a model for worlding. Therefore, SF must also mean 'so far,' opening up what is yet-to-come in protean entangled times' pasts, presents, and futures." 